\title{
Pengaruh Metode Bernyanyi Terhadap Penguasaan Kosakata Bahasa Inggris Siswa Kelas Rendah
}

\author{
Rima Budianingsih ${ }^{*}$, Arsyi Rizqia Amalia ${ }^{2}$, Irna Khaleda ${ }^{3}$ \\ ${ }^{1}$ Universitas Muhammadiyah Sukabumi, Sukabumi, Indonesia \\ ${ }^{2}$ Universitas Muhammadiyah Sukabumi, Sukabumi, Indonesia \\ 3 Universitas Muhammadiyah Sukabumi, Sukabumi, Indonesia \\ *Corresponding author: budianingsihrima@gmail.com
}

\begin{abstract}
This research aims to determine the effect of using the method in mastering the English vocabulary of low-grade students at SD Islam Al Azhar 7 Sukabumi City. The subjects in this research consisted of class III-B Madinah as a control class and class III-C Arafah as an experimental class which was carried out in the even semester of the 2020/2021 academic year. This research uses a quasi-experimental design method of pretest-posttest control group design. Data collection is done by using tests. The research instrument used in this research were pretest and posttest questions consisting of multiplechoice questions, short entries and matching questions with a total of 20 items. Before being used, it was tested on 22 grade III-A Makkah students. The data analysis technique used is quantitative by analyzing the data from the pretest and posttest results. Results based on the research, it shows that the average pretest value is 83 and the posttest value is 94 . Meanwhile, the significance value in the pretest results is 0.210 and the significance value in the posttest results is 0.349 , each of which has a significance value of more than 0.05. Hypothesis testing by testing two independent samples obtained a significance value of $0.003<0.05$, which means that there is a significant difference so that it can be stated that the use of the singing method has a significant positive effect on mastery of English vocabulary in low grades.
\end{abstract}

Keywords: english; singing method; vocabulary

\section{ABSTRAK}

Penelitian ini bertujuan untuk mengetahui pengaruh dari penggunaan metode bernyanyi terhadap penguasaan kosakata bahasa Inggris siswa kelas rendah di SD Islam Al Azhar 7 Kota Sukabumi. Subjek pada penelitian ini terdiri dari kelas III-B Madinah sebagai kelas kontrol dan kelas III-C Arafah sebagai kelas eksperimen yang dilaksanakan pada semester genap Tahun Pelajaran 2020/2021. Penelitian ini menggunakan metode quasi experimental design jenis pretest-postest control group design. Instrumen penelitian yang digunakan pada penelitian ini yaitu berupa soal pretest dan posttest yang terdiri dari soal pilihan ganda, isian singkat dan soal menjodohkan dengan jumlah soal sebanyak 20 butir. Sebelum instrumen digunakan terlebih dahulu di uji cobakan dan memperoleh hasil yang valid. Teknik analisis data yang digunakan yaitu kuantitatif dengan melakukan analisis data hasil pretest dan posttest. Berdasarkan hasil penelitian menunjukkan rata-rata nilai pretest sebesar lebih kecil daripada hasil nilai posttest. Sementara untuk nilai signifikansi pada hasil pretest yaitu sebesar 0,210 dan nilai signifikansi pada hasil posttest yaitu sebesar 0,349 yang masing-masing nilai signifikansi nya lebih dari 0,05. Pengujian hipotesis dengan uji $t$ dua sampel independen diperoleh nilai signifikansi sebesar 0,003 < 0,05 yang artinya terdapat perbedaan yang signifikan sehingga dapat dinyatakan bahwa penggunaan metode bernyanyi berpengaruh positif secara signifikan terhadap penguasaan kosakata bahasa Inggris siswa di kelas rendah.

Kata Kunci: bahasa inggris; kosakata; metode bernyanyi

\section{Pendahuluan}

Bahasa Inggris di Indonesia masih menjadi foreign language, bukan first atau second language seperti di beberapa negara pesemakmuran (Miranti et al., 2015: 167). Selaras dengan pendapat tersebut, di Indonesia masyarakat lebih sering menggunakan bahasa Sunda atau menggunakan bahasa dari daerah masing-masing dan bahasa Indonesia masih menjadi bahasa kedua, sehingga bahasa Inggris masih menjadi bahasa asing di masyarakat serta masih 
menjadi bahasa asing pada pembelajaran di sekolah dasar. Oleh karena itu, pola pengajaran bahasa Inggris yang lebih bersifat pengenalan (Febriyanto, 2015).

Mata pelajaran bahasa Inggris sebetulnya tidak diwajibkan di sekolah dasar. Namun sudah ada beberapa sekolah yang menerapkan mata pelajaran bahasa Inggris sejak mulai dari sekolah dasar. Meskipun pada penerapan mata pelajarannya bahasa Inggris masih menjadi mata pelajaran muatan lokal ataupun sebagai ekstrakulikuler. Salah satu keinginan sekolah adalah mengenalkan salah satu bahasa internasional ini lebih dini sehingga ketika para siswa masuk ke jenjang sekolah yang lebih tinggi mereka sudah lebih siap berkompetisi dengan siswa-siswa lain (Yektiningtyas \& Rahayu, 2017: 53). Maka dari itu dengan membekali siswa dengan bahasa Inggris pada saat mereka masih di sekolah dasar, itu sangat membantu mereka pada saat akan melanjutkan studi mereka ke jenjang yang lebih tinggi, bahkan berguna untuk berkompetisi di era globalisasi.

Menurut Suhardiana (2017: 2) bahasa Inggris memiliki empat keterampilan yang harus dikuasai yaitu listening, speaking, reading dan writing, ke empat keterampilan tersebut semuanya saling berkalitan. Hal ini selaras dengan pembelajaran bahasa Inggris di sekolah dasar yang mengajarkan siswa agar menguasai ke empat keterampilan bahasa Inggris tersebut. Namun tentu dalam proses menguasai ke empat keterampilan ini tidak bisa dilakukan secara bersamaan, harus berurutan dan sesuai dengan tingkatan.

Usia siswa sekolah dasar merupakan masa yang sangat penting dalam mempelajari bahasa Inggris terutama dalam menguasai empat keterampilan bahasa Inggris. Pada masa ini daya ingat siswa masih sangat kuat sehingga siswa dapat lebih mudah dalam mengingat dan menguasai suatu bahasa. Pada usia ini, sebaiknya siswa sudah mulai diperkenalkan dengan berbagai macam English vocabularies atau kosakata bahasa Inggris agar dapat mudah dipahami dan dikuasai. Memahami dan menguasai English vocabularies atau kosakata bahasa Inggris adalah hal yang paling mendasar bagi siswa sebelum menguasai ke empat keterampilan bahasa Inggris.

Pengajaran bahasa tidak hanya tentang mengajarkan ilmu pengetahuan, tetapi lebih pada mengajarkan keahlian, sehingga membutuhkan waktu yang lama untuk membuat seseorang lancar dalam menggunakan bahasa tersebut (Empati et al., 2018: 369). Maka dari itu perkembangan pemahaman dan penguasaan English vocabularies seseorang berpengaruh terhadap keterampilan dan kemampuan mengungkapkan ide secara tepat. English vocabularies atau kosakata bahasa Inggris merupakan suatu hal penting untuk dipahami dan dikuasai dalam mempelajari bahasa Inggris.

Jean Piaget dalam Maisaroh (2011: 21) mengungkapkan bahwa anak usia sekolah dasar (usia 7-11 tahun) berada pada tahap operasional konkret, yaitu pola pikir logis, tahap ini ditandai dengan adanya sistem operasi berdasarkan apa yang terlihat nyata. Maka dari itu, anak pada usia sekolah dasar hanya peduli pada hal yang konkret. Sementara bahasa Inggris merupakan bahasa yang masih asing bagi siswa, maka salah satu cara agar pembelajaran dapat menarik perhatian siswa adalah dengan penggunaan metode pembelajaran yang efektif dan menyenangkan bagi siswa.

Salah satu metode yang dapat digunakan untuk menguasai kosakata bahasa Inggris siswa adalah dengan menggunakan metode bernyanyi atau sing a song, agar siswa lebih tertarik serta termotivasi untuk meningkatkan minat dan menjadi lebih semangat dalam mengikuti pembelajaran bahasa Inggris. Dengan meminta siswa untuk bernyanyi, metode ini berperan 
penting untuk dapat mendukung perkembangan siswa (Lestari \& Erik, 2019: 3). Hal tersebut sejalan dengan pendapat (Davik, 2020: 16) yang menyatakan bahwa dengan bernyanyi, khususnya bagi siswa sekolah dasar bisa digunakan guna meningkatkan kemampuan berbicara anak, melatih pendengara serta melatih rasa percaya diri pada anak. Melalui bernyanyi juga membantu anak dalam kemampuan koordinasi saat siswa menari mengikuti irama atau nada pada saat bernyanyi, dengan bernyanyi juga dapat mengoptimalkan kecerdasan pada siswa.

Bernyanyi adalah salah satu metode pembelajaran yang menyenangkan untuk siswa, metode ini juga cukup banyak dimanfaatkan atau digunakan dalam dunia pendidikan terlebih pada pendidikan anak-anak. Fungsi dari bernyanyi atau sing a song yaitu dengan bernyanyi dapat melatih siswa dalam pembelajaran bahasa Inggris seperti kosakata, pengucapan serta kelancaran. Hal tersebut sejalan dengan pendapat (Prayudha \& Malik, 2021: 66) yang mengatakan bahwa dengan menerapkan metode bernyanyi dapat menarik perhatian siswa serta dapat membuat suasana pembelajaran di kelas lebih kondusif. Hal tersebut menandakan bahwa penggunaan metode bernyanyi dalam dunia Pendidikan ini cukup banyak digunakan, terlebih pada siswa sekolah dasar.

Pembelajaran menggunakan metode bernyanyi dapat digunakan sebagai cara lain untuk berkomunikasi dengan orang lain, kepada orang yang lebih tua ataupun yang lebih muda (Intani, 2012: 184). Pendapat tersebut sejalan dengan (Lešnik, 2020: 94) yang mengatakan bahwa melalui kegiatan bernyanyi, pengetahuan mengenai metode bernyanyi yang di selaraskan dengan pembelajaran sangat penting bagi pendidik dan menjadi dasar untuk pendekatan yang tepat untuk tingkat perkembangan siswa. Selaras dengan pendapat tersebut penguasaan kosakata yang baik akan membantu siswa untuk berkomunikasi dengan baik dan benar. Pada penggunaan metode bernyanyi dalam pembelajaran ini menggunakan lagu-lagu anak berbahasa Inggris seperti baba black sheep, twinkle-twinkle little star, if you-re happy and you know it, ataupun bisa juga dengan menggunakan lagu anak berbahasa Indonesia seperti lagu potong bebek angsa, cicak di dinding, dua mata saya, anak kambing saya, dan sebagainya. Namun lirik dalam lagu tersebut diganti serta disesuaikan dengan tema pembelajaran yang akan dipelajari.

Penggunaan metode bernyanyi ini juga bisa digunakan dalam pembelajaran daring atau study from home yaitu dengan mengajak siswa untuk bernyanyi bersama melalui aplikasi tatap muka secara virtual dengan lirik berisi English vocabulary atau kosakata bahasa Inggris dengan menggunakan nada lagu yang sebelumnya telah ditentukan oleh guru. Sejalan dengan perndapat tersebut, (Santosa \& Christupar, 2021: 5) juga mengatakan bahwa diperlukan variasi pada saat proses pembelajaran di kelas yang efektif, seperti hal nya penggunaan metode bernyanyi yang diharapkan dapat memengaruhi keaktifan dan hasil belajar siswa. Metode bernyanyi ini dapat menarik perhatian siswa serta dapat meningkatkan motivasi belajar siswa dalam mata pelajaran bahasa Inggris. Melalui metode bernyanyi juga diharapkan siswa dapat lebih mudah untuk menguasai kosakata siswa dalam belajar bahasa Inggris.

Adapun penelitian yang telah dilakukan oleh Imron dan Fajriyyah (2021: 55) dalam penelitiannya menjelaskan bahwa penggunaan metode bernyanyi berpengaruh secara signifikan terhadap kemampuan menghafal mufrodat pada pembelajaran bahasa Arab materi al-fawaakih siswa kelas I MI Baitul Huda Klampisan Ngaliyan Semarang. Hubungan penelitian yang relevan dengan penelitian ini yakni dalam hal penggunaan metode benyanyi 
yang digunakan untuk mengetahui pengaruh terhadap kemampuan menghafal mufrodat atau kosakata bahasa Arab. Ketika pembelajaran dengan menerapkan metode bernyanyi ini siswa menjadi lebih aktif dalam mengikuti kegiatan pembelajaran serta pembelajaran menjadi lebih optimal. Maka dari itu peneliti menyarankan penggunaan metode bernyanyi terhadap penguasaan kosakata bahasa Inggris siswa.

Pembelajaran bahasa Inggris dalam penguasaan kosakata pada umumnya hanya diajarkan dengan memberikan tugas kepada siswa untuk menghafalkan kata dan artinya saja tanpa adanya penggunaan metode sebagai langkah-langkah dalam pembelajaran. Penggunaan metode yang kreatif dan inovatif dapat memberikan hal yang baru dan menarik bagi siswa sekolah dasar.

Penguasaan kosakata bahasa Inggris bagi siswa usia sekolah dasar sangat penting karena diharapkan pada saat mereka lulus dari sekolah lanjutan tingkat atas mereka sudah menguasai banyak kosakata. Semakin banyak mereka menguasai kosakata maka semakin cepat mereka memahami apa yang mereka baca, dan proses dalam membaca juga memberikan kesempatan kepada mereka untuk menemukan dan mempelajari kata baru. Penguasaan kosakata adalah hal yang penting bagi siswa dalam mengenyam pendidikan, agar mereka bisa berkomunikasi dengan baik dan benar.

Sesuai dengan latar belakang yang telah dipaparkan, penulis sangat tertarik untuk mengujicobakan metode bernyanyi terhadap penguasaan kosakata bahasa Inggris siswa kelas rendah. Maka dari itu penelitian ini bertujuan untuk mengetahui pengaruh dari metode bernyanyi terhadap penguasaan kosakata bahasa Inggris siswa kelas rendah.

\section{Metode Penelitian}

Metode penelitian yang digunakan pada penelitian ini yaitu quasi experimental design dengan menggunakan pretest-posttest control group design. Metode ini melibatkan dua kelompok kelas yaitu kelas eksperimen yang pada saat proses pembelajarannya diterapkan metode bernyanyi, sedangkan kelas kontrol pada saat proses pembelajarannya diterapkan metode tanya jawab. Kedua kelas diberikan soal pretest terlebih dahulu guna mengetahui kemampuan awal siswa serta mengetahui apakah ada perbedaan antara kelas eksperimen dan kelas kontrol.

Setelah diberi soal pretest, dilanjutkan dengan penentuan kelas eksperimen dan kelas kontrol. Kemudian saat proses pembelajaran pada kelas eksperimen diberikan perlakuan dengan menggunakan metode bernyanyi, sedangkan saat proses pembelajaran pada kelas kontrol menggunakan metode tanya jawab. Setelah proses pembelajaran dilaksanakan dan kelas eksperimen telah diberi perlakuan, kedua kelas tersebut diberi soal posttest guna dianalisis perbedaan yang signifikan terhadap hasil akhir dari kedua kelas tersebut.

Setelah diketahui kemampuan awal siswa, selanjutnya yaitu menentukan kelas eksperimen dan kelas kontrol, kemudian pada kelas eksperimen saat proses pembelajarannya diberikan perlakuan atau treatment dengan menggunakan metode bernyanyi, sementara pada kelas kontrol saat proses pembelajarannya tidak diberikan perlakuan atau treatment menggunakan metode bernyanyi. Setelah treatment diberikan, kedua kelas tersebut diberikan soal posttest guna dianalisis perbedaan yang signifikan terhadap hasil akhir dari kedua kelas tersebut. 
Tabel 1. Tabel Desain Penelitian

\begin{tabular}{cccc}
\hline$E G$ & $\mathrm{O}_{1}$ & $\mathrm{X}$ & $\mathrm{O}_{2}$ \\
$C G$ & $\mathrm{O}_{3}$ & - & $\mathrm{O}_{4}$ \\
\hline
\end{tabular}

(Siyoto, 2015)

Waktu penelitian dilakukan pada semester genap tahun ajaran 2020/2021. Adapun sampel penelitian yang digunakan yaitu teknik sampling jenuh yang mana pada pemilihan sampel tidak dilakukan secara random. Berdasarkan teknik pengambilan sampel tersebut, subjek pada penelitian ini yaitu kelas III SD Islam Al Azhar 7 Kota Sukabumi yang terdiri dari dua kelas yaitu kelas III Madinah dan kelas III Arafah. Penelitian ini dilakukan guna mengetahui pengaruh dari metode bernyanyi terhadap penguasaan kosakata bahasa Inggris siswa kelas rendah.

İnstrumen yang digunakan dalam pengumpulan data penelitian ini adalah soal pretest dan posttest yang disebarkan melalui link google form yang sebelumnya soal ini telah diujicobakan dan memperoleh hasil yang valid. Penelitian ini dibatasi pada penguasaan kosakata bahasa Inggris yang diukur dengan menggunakan tiga indikator yaitu pronounciation (pengucapan), spelling (ejaan), dan meaning (makna). Setelah data terkumpul, data dianalisis dengan menggunakan aplikasi SPSS 22. Analisis Pengumpulan data yang dilakukan dalam penelitian ini ialah analisis data pretest dan postest dengan melakukan uji prasyarat analisis (uji normalitas dan homogenitas) lalu dilanjutkan dengan melakukan uji t dua sampel independen. Setelah analisis data pretest dan postest dilakukan, dilanjutkan dengan melakukan uji hipotesis untuk mengetahui dari metode bernyanyi, uji ini dilakukan dengan bantuan aplikasi SPSS 22 dengan melakukan uji t dua sampel independen.

\section{Hasil dan Pembahasan}

Penelitian ini dilaksanakan terhadap kelas eksperimen dan kelas kontrol melalui data hasil pretest dengan uji $\mathrm{t}$ dua sampel independen untuk mengetahui bahwa kedua kelas tersebut memiliki kemampuan awal yang sama. Selanjutnya dilakukan proses pembelajaran dan diberikan perlakuan menggunakan metode bernyanyi pada kelas eksperimen. Setelah diberikan perlakuan dilanjutkan dengan pemberikan soal posttest guna mengetahui hasil akhir siswa. Setelah data diperoleh, dilakukan pengujian data pretest dan data posttest dengan melakukan uji $\mathrm{t}$ dua sampel berpasagan untuk mengetahui adanya peningkatan hasil belajar. Setelah itu, dilakukan uji hipotesis dengan menggunakan uji $\mathrm{t}$ sampel independen guna mengetahui pengaruh dari penggunaan metode bernyanyi terhadap penguasaan kosakata bahasa Inggris pada siswa kelas III. Hasil uji hipotesis tersebut dapat dilihat pada tabel dibawah ini:

Tabel 2. Tabel Hasil Uji Hipotesis

\begin{tabular}{cccc}
\hline Kelompok & Mean & $\begin{array}{c}\text { Nilai Sig. (2- } \\
\text { tailed) }\end{array}$ & Keputusan \\
\hline $\begin{array}{c}\text { Kelas } \\
\text { Eksperimen } \\
\text { Kelas }\end{array}$ & 94 & 0,003 & $H_{0}$ ditolak \\
Kontrol & 89 & & \\
\hline
\end{tabular}


Berdasarkan tabel hasil pengujian hipotesis diatas, diperoleh nilai signifikansi sebesar 0,003 yang berarti nilai tersebut lebih kecil dibandingkan taraf signifikansi uji (sig.) 0,05 maka $H_{0}$ ditolak. Dapat ditarik kesimpulan bahwa terdapat pengaruh yang sinifikan dari penggunaan metode bernyanyi terhadap penguasaan kosakata bahasa Inggris siswa kelas rendah.

Penelitian ini dilaksanakan dalam empat kali pertemuan yaitu satu kali pertemuan untuk melakukan pretest kepada siswa kelas eksperimen dan kelas kontrol, satu kali pertemuan untuk proses pembelajaran pada kelas eksperimen dengan menggunakan metode bernyanyi dan satu kali pertemuan di hari yang sama untuk kelas kontrol tanpa menggunakan metode bernyanyi. Selanjutnya satu kali pertemuan untuk melakukan posttest kepada kedua kelas.

Hasil yang lebih baik didapatkan pada kelas eksperimen yang pada saat proses pembelajarannya menggunakan metode bernyanyi dalam melatih penguasaan kosakata bahasa Inggris. Pada saat proses pembelajaran di kelas eksperimen, siswa dilatih untuk memahami arti dari setiap kosakata, melatih ejaan dari setiap kata, dan juga melatih pengucapan yang baik dan benar dari setiap kosakata bahasa Inggris. Penggunaan metode bernyanyi yang digunakan pada saat proses pembelajaran ini mampu membantu siswa dalam meningkatkan penguasaan kosakata bahasa Inggris.

Temuan ini didukung oleh (Rokhmah et al., 2014) yang mengemukakan bahwa bernyanyi dapat melatih peningkatan kosakata serta ingatan memori otak siswa, membentuk rasa percaya diri siswa dan menjadikan pikiran lebih segar sehingga siswa lebih senang dalam mengikuti kegiatan belajar dan akan memperoleh hasil belajar yang baik. Selain itu, metode benyanyi juga membantu serta memotivasi siswa agar lebih bersemangat dalam belajar dan meningkatkan penguasaan kosakata bahasa Inggris mereka.

Hasil penelitian ini selaras dengan pendapat Lestari \& Erik (2019: 3) yang mengungkapkan bahwa bernyanyi dapat menambah pembendaharaan kata, pada saat bernyanyi anak dapat mendengar sekaligus menghafal kosakata sehingga siswa akan terangsang untuk mengungkapkan atau mengatakannya. Pada saat proses pembelajaran ditemukan bahwa melalui bernyanyi siswa terangsang untuk mengikuti dan mengucapkan lirik dalam nada lagu serta mudah untuk menghafal kosakata dalam nyanyian tersebut.

Temuan dalam penelitian ini juga selaras dengan pendapat Yamin (2017: 91) yang menyatakan bahwa bernyanyi memiliki banyak manfaat untuk digunakan dalam pembelajaran bahasa Inggris diantaranya yaitu, dengan bernyanyi siswa lebih termotivasi dan lebih senang dalam mempelajari bahasa Inggris, siswa juga lebih mudah dalam memahami materi ajar yang disampaikan guru, melalui benyanyi juga kegiatan pembelajarn menjadi lebih variatif dan membuat siswa tidak merasa bosan dalam mengikuti proses pembelajaran.

Hal tersebut sesuai dengan pendapat Griffee dalam Ratminingsih (2016: 31) yang mengemukakan bahwa bernyanyi sebagai classroom atmosphere serta teaching and student interest yang berarti bahwa pada pelaksanaan bernyanyi menjadikan suasana kelas menjadi lebih menyenangkan dan bernyanyi juga dapat mengajarkan percakapan, kosakata, struktur gramatika, lafal, latihan pola, dan penguatan ingatan. Hal tersebut selaras dengan temuan peneliti yang menemukan bahwa bernyanyi dapat mengubah suasana kelas menjadi lebih ceria serta menyenangkan, serta dengan bernyanyi siswa juga lebih mudah mengingat berbagai kosakata karena kata tersebut terus diulang dan disebutkan dalam lirik lagu yang dinyanyikan. 
Akan tetapi pada saat pelaksanaan penelitian ini, ada beberapa kendala yang didapatkan oleh peneliti, yaitu berkaitan dengan masalah jaringan. Pada saat peneliti melaksanakan proses pembelajaran melalui aplikasi zoom meeting terkadang mendapati koneksi yang memburuk sehingga pada saat proses pembelajaran koneksi menjadi terputus dan tertunda hingga beberapa saat.

Sementara temuan pada proses pembelajaran di kelas kontrol yaitu kelas III-B Makkah ialah kelas yang tidak diberikan perlakukan menggunakan metode bernyanyi pada saat proses pembelajarannya adalah pada saat awal pembelajaran siswa sulit untuk mengeja dan juga membedakan pengucapan dari setiap alfabet bahasa Inggris. Namun, karena karakter dasar yang dimiliki oleh siswa kelas kontrol ini aktif dan juga senang untuk mengetahui hal baru, siswa menjadi aktif pada saat pembelajaran berlangsung sehingga mereka sangat mudah untuk mencari tahu arti dari setiap kosakata, ejaan, dan juga pengucapan dari setiap kosakata bahasa Inggris hanya dengan melakukan metode tanya jawab dan juga pemberian beberapa kuis.

Berdasarkan data hasil analisis nilai pretest dan posttest yang sudah dilakukan pada kelas eksperimen dan kelas kontrol diperoleh hasil bahwa siswa yang pada proses pembelajarannya menggunakan metode bernyanyi mengalami peningkatan dan juga memiliki rata-rata yang lebih tinggi dari siswa yang pada saat proses pembelajarannya tidak menggunakan metode bernyanyi.

Nilai rata-rata hasil pretest kelas kontrol yaitu 86 sementara kelas eksperimen yaitu 83, hal tersebut selaras dengan hasil uji $\mathrm{T}$ dua sampel independen yang menunjukkan nilai signifikansi (sig.) sebesar 0,030. Nilai tersebut lebih kecil dari taraf signifikansi yaitu 0,05, sehingga $H_{0}$ diterima dan $H_{1}$ ditolak yang artinya bahwa kelas kontrol dan kelas eksperimen memiliki kemampuan awal yang sama.

Setelah dilaksanakannya penelitian, didapatkan hasil siswa yang pada saat proses pembelajarannya menggunakan metode bernyanyi memperoleh nilai rata-rata sebesar 94, sedangkan hasil siswa yang pada proses pembelajarannya tidak menggunakan metode bernyanyi memperoleh nilai rata-rata sebesar 89. Selain itu, berdasarkan hasil perbandingan antara nilai pretest dan nilai postest pada kelas kelas eksperimen menggunakan uji $\mathrm{t}$ dua sampel berpasangan diperoleh nilai signifikansi (sig.) sebesar 0,000 yang berarti nilai tersebut lebih kecil dari taraf signifikansi 0,05 sehingga $H_{0}$ ditolak dan $H_{1}$ diterima, yang artinya ratarata nilai posttest lebih baik dari nilai pretest.

Berdasarkan penjelasan diatas, dapat diperoleh kesimpulan bahwa nilai rata-rata kelas eksperimen yang pada saat proses pembelajarannya menggunakan metode bernyanyi lebih tinggi dibandingkan dengan kelas kontrol yang pada saat proses pembelajarannya tidak menggunakan metode bernyanyi. Hal tersebut dapat dilihat pada grafik perbandingan ratarata nilai pretest dan posttest kelas kontrol dan kelas eksperimen dibawah ini: 


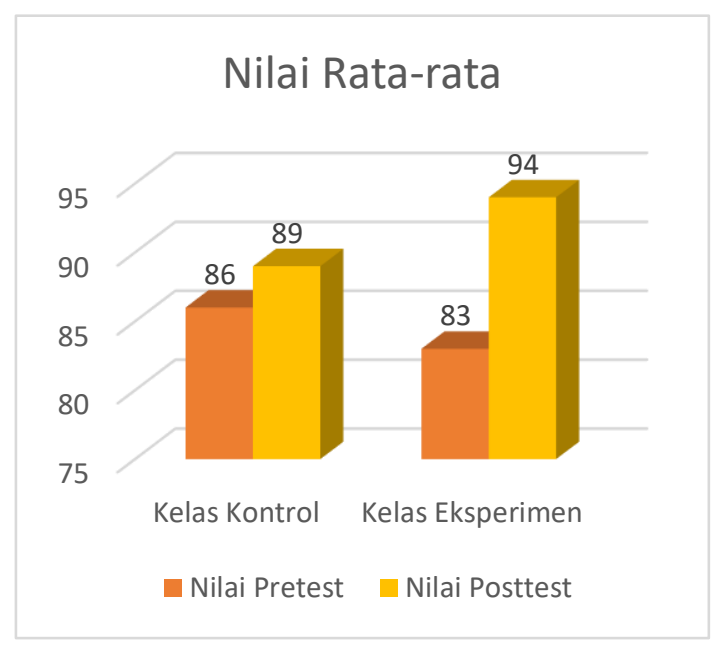

Gambar 1. Grafik Perbandingan Rata-rata Nilai Pretest dan Posttest pada Kelas Eksperimen dan Kelas Kontrol

Berdasarkan diagram diatas dapat diketahui bahwa rata-rata nilai posttest pada kelas eksperimen meningkat sebesar 11 poin yang berarti kelas tersebut mempunyai peningkatan yang signifikan. Hal tersebut menunjukkan bahwa terdapat pengaruh yang signifikan dari penggunaan metode bernyanyi terhadap penguasaan kosakata bahasa Inggris siswa kelas rendah.

\section{Kesimpulan}

Berdasarkan hasil pengujian serta hasil penelitian dan pembahasan yang telah dilaksanakan peneliti bahwa terdapat perbedaan dari hasil akhir siswa yang pada saat proses pembelajarannya menggunakan penerapan metode bernyanyi dengan siswa yang pada saat proses pembelajarannya tanpa menggunakan metode bernyanyi. Berdasarkan hal tersebut, dapat disimpulkan penggunaan metode bernyanyi memberikan pengaruh positif yang signifikan terhadap penguasaan kosakata bahasa Inggris siswa kelas III.

\section{Daftar Pustaka}

Davik. (2020). Implementasi Metode Bernyanyi dalam Meningkatkan Penguasaan Mufrodat Bahasa Arab Siswa. Jurnal Lughoti: Jurnal Pendidikan Bahasa Arab, 1(02), 1-26.

Empati, J., Putri, A. K., \& Ariati, J. (2018). Pengaruh Permainan Story Card Terhadap Kemampuan Mengingat Kosakata Bahasa Inggris. Empati, 7(2), 368-375.

Febriyanto, B. (2015). Make a Match Dalam Pembelajaran Writing Di Kelas V Sekolah Dasar. Jurnal Cakrawala Pendas, 1(2). https://doi.org/10.31949/jcp.v1i2.765

Intani, eka nur. (2012). Developing Modified Indonesian Children Song Lyrics To Teach Vocabulary To Elementary School Third Graders. English Education Journal (Program Pascasarjana Universitas Negeri Semarang), 2(2), 183-188.

Lešnik, I. (2020). Correlation of teachers and pupils in the context of singing in primary school. The New Educational Review, 62, 93-102. https://doi.org/10.15804/tner.2020.62.4.08

Lestari, A. A., \& Erik. (2019). Penggunaan Metode Bernyanyi Terhadap Peningkatan Kosakata Bahasa Inggris. Jurnal Pendidikan, 1(1), 1-14.

Maisaroh, N. (2011). Fun Lyrics (Fl): Pengembangan Media Belajar Bahasa Inggris untuk Siswa 
Sekolah Dasar Melalui Lirik Musik. Pelita, VI(2), 1-14.

Miranti, I., Engliana, \& Hapsari, F. S. (2015). Penggunaan Media Lagu Anak-Anak Dalam Mengembangkan Kemampuan Kosakata Bahasa Inggris Siswa Di PAUD. Jurnal Ilmiah Kependidikan, II(No. 2 Juli), 167-173.

Prayudha, J., \& Malik, A. A. (2021). The Implementation of Singing Method to Increase Student Interests in Learning at TK Negeri Pembina Lebong. Sistema: Jurnal Pendidikan, 2(4), 33 42.

Ratminingsih, N. . (2016). Efektivitas Media Audio Pembelajaran Bahasa Inggris Berbasis Lagu Kreasi di Kelas Lima Sekolah Dasar. Jurnal Pendidikan Indonesia, 5(1), 27-38.

Rokhmah, K., Suryandari, kartika chrysti, \& Wahyudi. (2014). Penggunaan Metode Sing A Song dalam Upaya Peningkatan Motivasi dan Hasil Belajar Bahasa Inggris Siswa Kelas IV SDN Tegalsari. Kalam Cendekia, 5(1.1), 36-42.

Santosa, D. S. S., \& Christupar, M. (2021). Pengaruh Penggunaan Media Pembelajaran Lagu Terhadap Keaktifan Siswa dan Hasil Belajar Siswa di Kelas 3 SD Kristen Saint John Bekasi. Pendas: Jurnal Ilmiah Pendidikan Dasar, VI(01).

Siyoto, S. (2015). Dasar Metodologi Penelitian. Literasi Media Publishing.

Suhardiana, I. P. A. (2017). Optimalisasi Penguasaan English Vocabulary Melalui Pemanfaatan Media Ludo Words Game (LWG) pada Siswa Sekolah Dasar. Adi Widya : Jurnal Pendidikan Dasar, 1(April), 1-10.

Yamin, M. (2017). Metode Pembelajaran Bahasa Inggris Di Tingkat Dasar. Pesona Dasar (Jurnal Pendidikan Dasar Dan Humaniora), 1(1), 82-97.

Yektiningtyas, W., \& Rahayu, B. (2017). Pembelajaran bahasa inggris untuk sekolah dasar melalui cerita rakyat anak papua. Jurnal Pengabdian Papua, 1(2), 53-58. 